\title{
PHENOLOGY OF FLOWERING AND POLLEN RELEASE OF SELECTED HERBACEOUS PLANTS IN SZCZECIN AND GUDOWO (WESTERN POMERANIA) AND THE RISK OF POLLEN ALLERGY
}

\author{
Aleksandra Kruczek, Małgorzata Puc \\ University of Szczecin, Department of Botany and Nature Conservation, Z. Felczaka 3c, 71-412 Szczecin, Poland \\ e-mail: aleksandra_kruczek@10g.pl
}

Received: 02.09.2012

\begin{abstract}
This paper presents the course of the pollen season of selected allergenic taxa (Secale spp., Rumex spp., Plantago spp., Urtica spp., Artemisia spp., Chenopodiaceae and Poaceae) in Szczecin (2009) and Gudowo (Western Pomerania, Poland) (2009-2010), and also the flowering pattern of Chenopodium album, Artemisia vulgaris and Secale spp. Pollen deposition was studied by the gravimetric method using a Durham sampler. In 2010 the flowering period of the studied taxa was shorter than in 2009 and its onset was observed later; the maximum values of daily pollen deposition were lower. Pollen grains of most of the taxa studied appeared in the atmosphere of the city earlier than in the rural area, but in the rural area significantly higher values of daily deposition were recorded. The effect of weather conditions on pollen fall in Szczecin in 2009 was analysed. Statistically significant positive correlations with pollen deposition were found only with maximum, minimum, and mean air temperature, dew point and maximum wind speed, while a negative correlation was found with precipitation and - only for Rumex pollen grains - with air humidity and pressure.
\end{abstract}

Key words: pollen fall, phenology of flowering, herbaceous plants

\section{INTRODUCTION}

The contribution of different pollen-producing plant species to the vegetation of a region, the number of flowers and inflorescences, along with anther productivity, the effects of weather conditions and abiotic factors all determine the pollen count in the air and thus its potentially allergenic effect (M y s z k ow s k a et al. 2010). Analysis of phenological phenomena is important also for the preparation of a regional pollen calendar predicting the periods of increased pollen count, which is important in pollinosis prevention ( $\mathrm{We} \mathrm{-}$
ryszko-Chmielewska et al. 2007). Allergy to pollen is a systemic disease estimated to occur in $10-15 \%$ of human population. Among pollen of herbaceous plants, allergens of grass pollen are most often responsible for the symptoms of pollinosis ( $\mathrm{R}$ a p i e j k o, 1997, L e u s c h n e r et al. 2000). In the majority of pollinosis sufferers, the symptoms of the disease appear at a concentration of over 50 grass pollen grains in $1 \mathrm{mt}$ of air. Poaceae pollen reaches very high daily values (Rapiejko and Lipiec, 2005; Lipiec et al. 2006; P u c , 2011), and grass has a long blooming period - from May to October ( $\mathrm{C} \mathrm{h} \mathrm{f} \mathrm{o} \mathrm{p} \mathrm{e} \mathrm{k} \mathrm{et} \mathrm{al.} \mathrm{2007).}$ Mugwort, which produces flowers in late summer, is also important for allergology, since its pollen reaches very high values, often $400-500$ grains in $1 \mathrm{ml}$ of air. In $80 \%$ of sufferers, the disease symptoms occur at the mean daily pollen count of 40-60 grains per $1 \mathrm{mł}$ of air. Persons allergic to mugwort pollen can develop two clinical syndromes referred to as the mugwort - celery spice syndrome and the mugwort - mustard syndrome (Rapiejko and Weryszko-Chmielewska, 1999; R a piejk o and Lipie c, 2006). The pollens from plantain, sorrel, nettle and goosefoot rarely produce allergy symptoms, but they become important for sufferers of advanced pollinosis (Myszkowska et al. 2007; R a piejk o, 1997; Wery szko- Chmielewska and Pi otrowska, 2004).

In Poland there are about 200 grass species. They form many communities, such as steppes, savannahs, meadows, which occupy nearly L of the area of land covered with vegetation. A single flower of rye produces 57,000 pollen grains and $1 \mathrm{~m}$, of rye produces over 1.5 billion grains ( $\mathrm{S}$ z w e y k o w s c y, 1995; $\mathrm{R}$ a p i e j k o, 1997). The genus Rumex comprises about 200 species of plants from the temperate climate 
zone of the northern hemisphere. The common species in Poland are Rumex acetosa and R. crispus. In Poland the most abundantly represented plantain species are as follows: Plantago maior, P. lanceolata, and P. minor. The genus Urtica comprises about 33 plant species occurring in the temperate climate zone, among which Urtica dioica and $U$. urens are species that are commonly found in Poland. The family Chenopodiaceae, including cosmopolitan weeds and ruderal plants, is represented in Poland by many species, e. g. Chenopodium album, Ch. bonus-henricus, Ch. glaucum, and Ch. rubrum. From the genus Artemisia, apart from the common ruderal species Artemisia vulgaris, in Poland there are also A. absinthium, A. abrotanum, A. dracunculus, A. campestris, A. pontica, and A. maritima (S zweykowscy, 1993; Rapiejko and Weryszko-Chmi elewska, 1999).

Pollen fall is most often determined by the gravimetric method, which is not only simple and inexpensive but, first of all, highly sensitive to local changes in this parameter. Besides the Durham pollen trap (D u r h a m, 1946), Tauber traps are also used. This method is commonly used in Europe within the Pollen Monitoring Programme, which is an international project for the measurement of deposition of pollen grains of taxa important from the point of view of paleoecological studies in regions with different types of vegetation and climate (Pi de k et al. 2009). Gravimetric measurements allow the detection of large numbers of redeposited pollen grains, especially those of Poaceae. Results obtained by the gravimetric method are more dependent on weather conditions, in particular precipitation, than those obtained by the volumetric method (Piotrowska and Weryszko-Chmielew s k a , 2003). Results obtained by these two methods concerning the length and dynamics of pollen seasons, trends towards an increase or decrease in the pollen count and periods of high pollen count in the atmosphere are comparable (O'R ourke, 1990; Pi otrowska and Weryszko-Chmielewska, 2003). Measurements performed using the gravimetric method have been made by, e.g., $\mathrm{Zaw}$ is z a et al. (1993) in Warsaw, Piotrowska and Weryszko-Chmielewska (2003) in Lublin, Pidek (2006) in Roztocze, Le vetin (2000) in the USA, and K o to et al. (1998) in Japan.

The aim of this study was to analyse the flowering and pollen release of Chenopodium, Artemisia and Secale in relation to the pollen count of these plants in the air in Gudowo in the years 2009-2010 and in Szczecin in 2009. The influence of weather factors on airborne pollen counts for herbaceous plants and the threats to pollinosis sufferers related to pollen allergens (pollen calendars) were also studied.

\section{MATERIALS AND METHODS}

Phenological observations and measurements of the rate of growth of inflorescences of Chenopodium album L., Artemisia vulgaris L. and Secale cereale L., were made in the years 2009-2010 at five sites in Gudowo village. In the period from April $12^{\text {th }}$ to August $12^{\text {th }}, 2009$, and from May $22^{\text {nd }}$ to August $15^{\text {th }}$, each day the length of 20 selected inflorescences was measured and then the mean values were calculated. The Łukasiewicz method (1984) was used to record the successive phenophases (F) of the generative development of plants:

Appearance of the first flowers or inflorescence buds; alder and hazel set inflorescence buds in late summer of the previous year, so phase F1 was counted from the 1st of January, therefore the first phenological observations started from phase F2;

F1 Blooming of the first flowers;

F2 Beginning of full flowering (25\% of flowers open);

F3 First flowers being shed (withered);

F4 End of full flowering ( $75 \%$ of flowers open);

F5 Last flower buds;

F6 End of flowering (from the day when the last flowers finished blooming until the end of June; the end of June was chosen arbitrarily). The peak pollen release period includes phases from F3 to F5.

Pollen deposition of Secale spp., Rumex spp., Plantago spp., Urtica spp., Artemisia spp., Chenopodiaceae and Poaceae was measured by the gravimetric method, using a Durham pollen trap, at two sam-

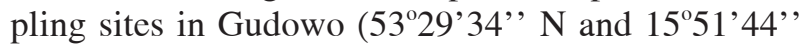
$\mathrm{E})$, at $1.5 \mathrm{~m}$ above the ground, and in the centre of Szczecin (53'26'23' $\mathrm{N}$ and $\left.14^{\circ} 32^{\prime} 53^{\prime \prime} \mathrm{E}\right)$, at $21 \mathrm{~m}$ above the ground on the roof of the Faculty of Biology building. In Gudowo the observations were made in 2009-2010, while in Szczecin in 2009. The gravimetric method is based on the assumption that the number of pollen grains that fell on the catching surface reflects the species composition of pollen-producing plants and their quantitative contributions. The catching surface is that of a microscopic slide coated with a thin layer of glue (D y bova - J a chowi c z and $\mathrm{S}$ adow ska, 2003). In the pollen trap, microscopic slides were changed every second day. The pollen deposit was analysed under a light microscope at a magnification of $480 \times$. The results are expressed as the number of pollen grains deposited on an area of $1 \mathrm{~cm}^{2}$ of the catching surface in a time unit. The pollen season (PS) in particular years was counted as the period from which the sum of daily mean pollen 
concentrations reaches $1 \%$ of the total sum until the time when the sum reaches $99 \%$, i.e. the time with $98 \%$ of the total pollen count $(98 \%$ method) (E m berlin et al. 1993).

The weather data for Szczecin in 2009 were obtained from the automatic meteorological station Vaisala (Helsinki, Finland). The parameters used for the evaluation of the effect of weather conditions on the pollen count were as follows: mean, minimum and maximum air temperature, relative air humidity, precipitation and wind speed. Statistical analysis was made using Spearman's correlation rank coefficient for $\mathrm{p}<0.05$ and the program Statistica StatSoft, Inc. (2008).

\section{RESULTS}

In 2010 the flowering period of the taxa studied started later and was shorter than that in 2009. The flowering period of rye and goosefoot was shorter by 4 days and that of mugwort was shorter by 10 days (Fig. 1). Notable differences were observed in the dates of successive phenophases and their duration; in particular phenophase $F_{3}$ was much shorter, as it lasted from the full bloom date to first wilting. Total pollen deposition from these taxa was a few times lower than in 2009: for Secale - by 3.7x, Chenopodiaceae $-5.3 \mathrm{x}$, and Artemisia - by $6.1 \mathrm{x}$.

The rye pollen count in the air increased with the development of inflorescences, while the Artemisia pollen count increased after the mass bloom stage and after the inflorescences had reached the greatest size. In 2009 the full flowering period for Artemisia vulgaris, Chenopodium album and Secale cereale in Gudowo lasted from July $15^{\text {th }}$ to $23^{\text {rd }}$, June $18^{\text {th }}$ to July $1^{\text {st }}$, May $25^{\text {th }}$ to June $3^{\text {rd }}$, respectively, while in 2010 it was July $26^{\text {th }}-30^{\text {th }}$, June $16^{\text {th }}-19^{\text {th }}$, June $9^{\text {th }}-14^{\text {th }}$. The maximum values of pollen deposition for mugwort, goosefoot and rye were recorded in 2009 on August $6^{\text {th }}-9^{\text {th }}$, August $20^{\text {th }}-21^{\text {st }}$, May $30^{\text {th }}-31^{\text {st }}$, while in 2010 on August $13^{\text {th }}-14^{\text {th }}$, August $5^{\text {th }}-6^{\text {th }}$, and June $10^{\text {th }}-11^{\text {th }}$. Single grains of the pollen of Artemisia, Chenopodiaceae and Secale were in the air for a few weeks after inflorescence wilting. According to the measurements of the height of the plants studied in these two consecutive years, the individuals of Artemisia vulgaris and Chenopodium album in 2010 were smaller than in 2009. The probable reason was drought and high temperatures in 2010 during the growing season. Clear differences in the duration of the particular phenophases of the species studied were observed between 2009 and 2010. In 2010 Secale cereale started to shed pollen much earlier than in 2009. The peak pollen shed period of rye coincided with the period of the highest concentrations, and the amounts of pollen recorded during different phenophases varied in each year (Fig. $1 \mathrm{a}, \mathrm{b}$ ). However, the highest amount of Artemisia and Chenopodiaceae pollen was found after the end of the peak pollen release period (F5) (Fig. 1, Table 1).

Pollen grains of the majority of taxa studied appeared in the city earlier by two weeks than in the rural area, only pollen grains from Urtica and Chenopodiaceae were observed earlier by about a month in the air of Gudowo village (Fig. 2). Also in Gudowo daily pollen deposition for all the taxa studied was much higher. The maximum daily deposition for Poaceae pollen in both seasons was twice higher in the country. The difference was interpreted as a result of a greater contribution of grass to the vegetation of Gudowo and the location of the sampling instrument near meadows and grasslands (Table 1). The majority of the taxa studied began flowering earlier in the city, but the mean pollen count in the air was higher in the country. The differences in the flowering pattern of rye, goosefoot and mugwort in the 2009 and 2010 seasons were most probably related to different weather conditions and a different character of the sites at which the phenological observations were made.

Pollen calendars present patterns in pollen seasons for each allergenic taxon from the selected group of plants. In the pollen calendars for Gudowo and Szczecin, the longest pollen seasons were observed for grasses and the percentage of grass pollen in the annual sum of pollen from the taxa analysed was the highest - over 60\%. In Gudowo in 2010 rye pollen remained in the air longer than in 2009 and its deposition was lower. The calendars for Szczecin and Gudowo recorded long pollen seasons and low pollen deposition for sorrel and plantain. Mugwort and goosefoot pollen grains were the latest to appear in the air and their proportion in the total pollen count was the lowest. In 2010 daily pollen deposition for herbaceous plants was lower and the maximum monthly counts were recorded in later months than in 2009 (Fig. 2).

As to the effect of weather elements, statistically significant positive correlations were found between the pollen count and maximum, minimum and mean air temperatures, dew point and maximum wind speed, while statistically significant negative correlations were found between the pollen count and precipitation, and only for Rumex pollen - in relation to air humidity and atmospheric pressure (Table 2 ). 

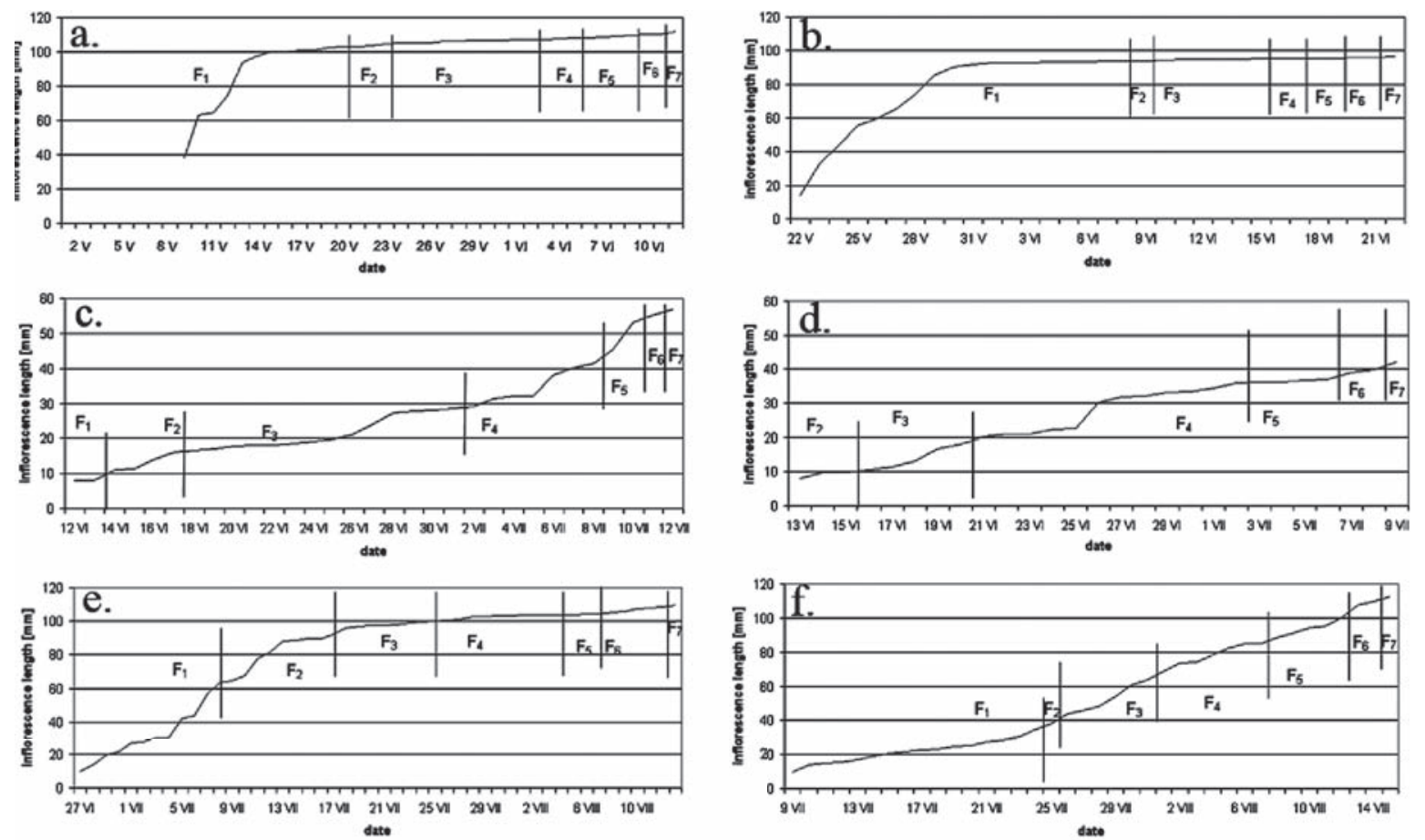

Fig. 1. Rate of growth of inflorescences and the phenophases identified: a - Secale cereale in 2009; b - Secale cereale in 2010; c Chenopodium album in 2009; d - Chenopodium album in 2010; e-Artemisia vulgaris in 2009; f-Artemisia vulgaris in 2010.
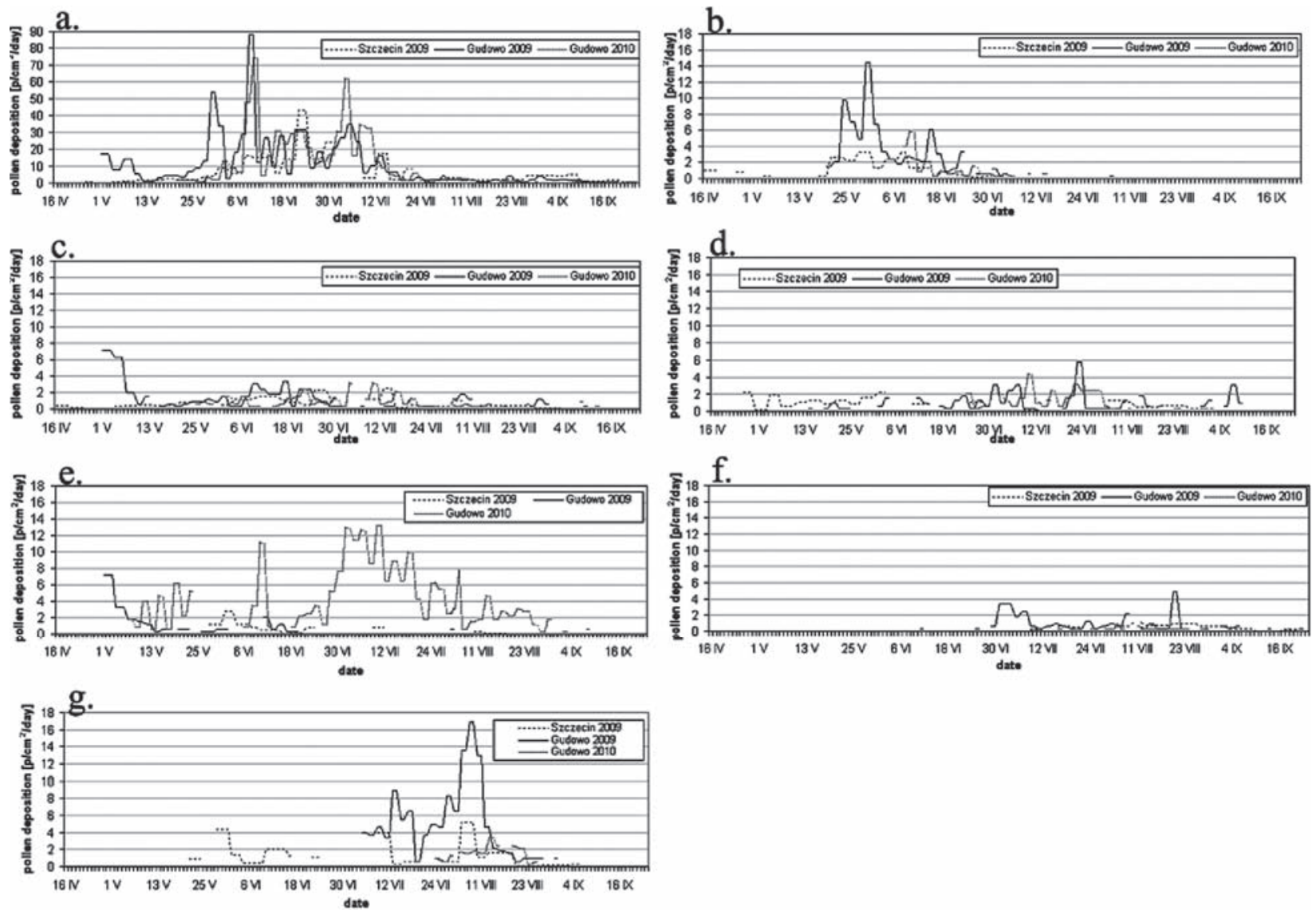

Fig. 2. Pollen deposition of selected taxa in Szczecin and Gudowo (2009) and in Gudowo (2010): a- Poaceae; b - Secale; c - Rumex; $\mathrm{d}$ - Plantago; e - Urtica; f - Chenopodiaceae; g-Artemisia (change of scale: Poaceae). 


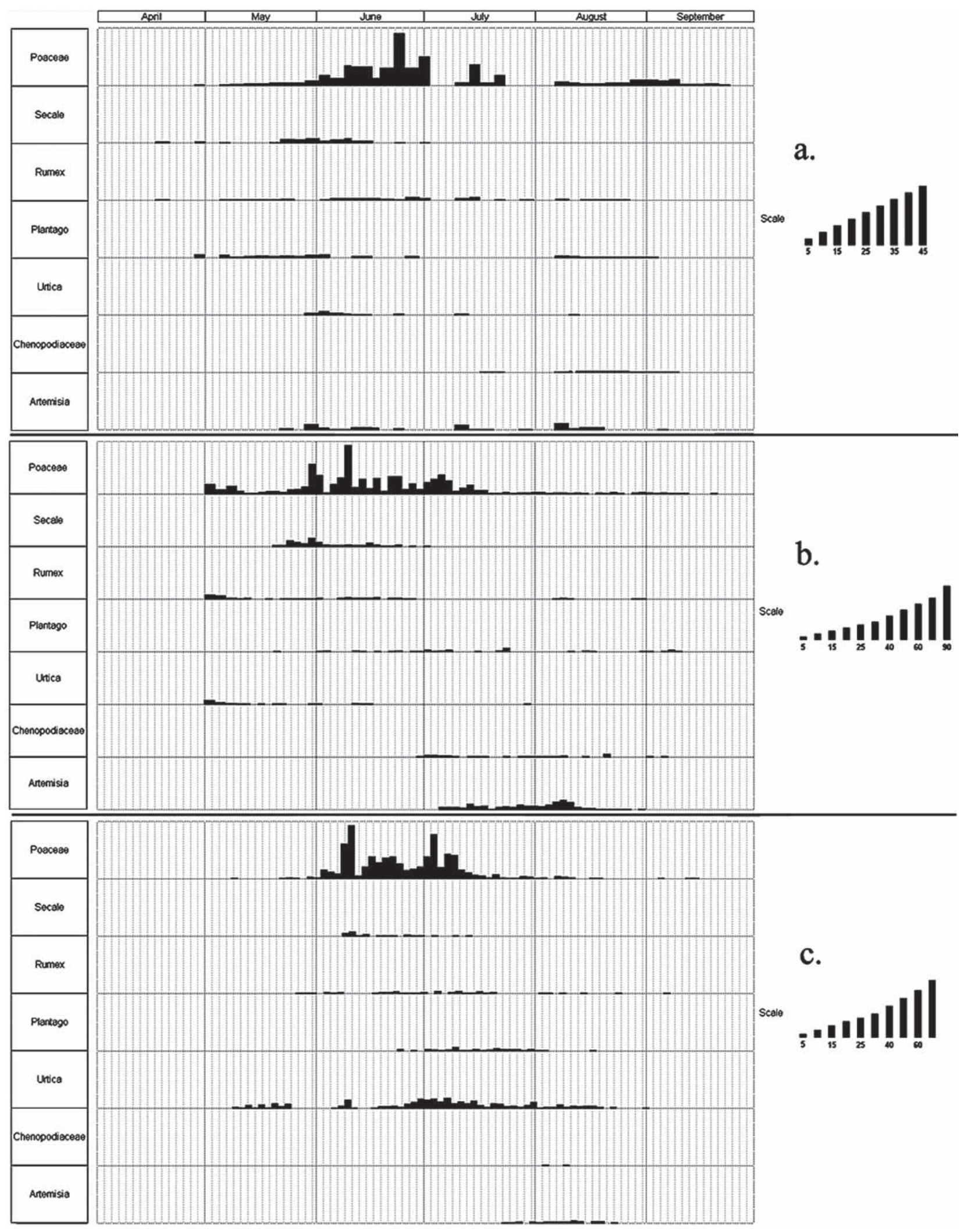

Fig. 3. Pollen calendar: a - Szczecin 2009; b - Gudowo 2009; c - Gudowo 2010. 
Table 1

Characteristics of the pollen seasons (98\% of total pollen deposition)

\begin{tabular}{|c|c|c|c|c|c|c|c|c|c|}
\hline \multirow[b]{2}{*}{ Taxon } & \multicolumn{3}{|c|}{ Presence in aeroplankton } & \multicolumn{3}{|c|}{ The highest concentration } & \multicolumn{3}{|c|}{ Maximum daily deposition (grains / $\mathrm{cm}^{2} /$ day) } \\
\hline & $\begin{array}{c}\text { Szczecin } \\
2009\end{array}$ & $\begin{array}{c}\text { Gudowo } \\
2009\end{array}$ & $\begin{array}{c}\text { Gudowo } \\
2010 \\
\end{array}$ & $\begin{array}{c}\text { Szczecin } \\
2009\end{array}$ & $\begin{array}{c}\text { Gudowo } \\
2009\end{array}$ & $\begin{array}{c}\text { Gudowo } \\
2010 \\
\end{array}$ & $\begin{array}{c}\text { Szczecin } \\
2009\end{array}$ & $\begin{array}{c}\text { Gudowo } \\
2009 \\
\end{array}$ & $\begin{array}{c}\text { Gudowo } \\
2010 \\
\end{array}$ \\
\hline Poaceae & $\begin{array}{c}27 \text { IV } \\
-23 \text { IX }\end{array}$ & $\begin{array}{c}1 \mathrm{~V} \\
-20 \mathrm{IX}\end{array}$ & $\begin{array}{c}7 \mathrm{~V} \\
-25 \mathrm{IX}\end{array}$ & June & June & June & $\begin{array}{c}43.16 \\
(22-24 \mathrm{VI})\end{array}$ & $\begin{array}{c}88.05 \\
(9-10 \mathrm{VI})\end{array}$ & $\begin{array}{c}74.19 \\
(10-11 \mathrm{VI})\end{array}$ \\
\hline Secale & $\begin{array}{l}16 \mathrm{IV} \\
-1 \mathrm{VII}\end{array}$ & $\begin{array}{c}20 \mathrm{~V} \\
-4 \mathrm{VII}\end{array}$ & $\begin{array}{c}8 \mathrm{VI} \\
-15 \mathrm{VII}\end{array}$ & May/June & May & June & $\begin{array}{c}3.32 \\
(8-9 \mathrm{VI})\end{array}$ & $\begin{array}{c}14.47 \\
(30-31 \mathrm{~V})\end{array}$ & $\begin{array}{c}5.85 \\
(10-11 \mathrm{VI})\end{array}$ \\
\hline Rumex & $\begin{array}{l}16 \mathrm{IV} \\
-3 \mathrm{IX}\end{array}$ & $\begin{array}{c}1 \mathrm{~V} \\
-10 \mathrm{IX}\end{array}$ & $\begin{array}{c}25 \mathrm{~V} \\
-13 \mathrm{IX}\end{array}$ & June & May & July & $\begin{array}{c}2.49 \\
(13-15 \mathrm{VII})\end{array}$ & $\begin{array}{c}7.18 \\
(1-3 \mathrm{~V})\end{array}$ & $\begin{array}{c}3.08 \\
(4-5,10-11 \mathrm{VII})\end{array}$ \\
\hline Urtica & $\begin{array}{c}28 \mathrm{~V} \\
-19 \mathrm{VIII}\end{array}$ & $\begin{array}{c}1 \mathrm{~V} \\
-20 \mathrm{VI}\end{array}$ & $\begin{array}{c}7 \mathrm{~V} \\
-9 \mathrm{IX}\end{array}$ & June & May & July & $\begin{array}{c}2.77 \\
(1-3 \mathrm{VI})\end{array}$ & $\begin{array}{c}7.18 \\
(1-3 \mathrm{~V})\end{array}$ & $\begin{array}{c}13.24 \\
(10-11 \mathrm{VII})\end{array}$ \\
\hline Plantago & $\begin{array}{l}27 \mathrm{IV} \\
-3 \mathrm{IX}\end{array}$ & $\begin{array}{c}14 \mathrm{~V} \\
-10 \mathrm{IX}\end{array}$ & $\begin{array}{l}18 \mathrm{VI} \\
-1 \mathrm{IX}\end{array}$ & May & July & July & $\begin{array}{c}2.21 \\
(27-29 \mathrm{IV}, 1-3 \mathrm{VI})\end{array}$ & $\begin{array}{c}5.85 \\
(23-24 \text { VII })\end{array}$ & $\begin{array}{c}4.31 \\
(10-11 \mathrm{VII})\end{array}$ \\
\hline Chenopodiaceae & $\begin{array}{c}9 \mathrm{VII} \\
-20 \mathrm{IX}\end{array}$ & $\begin{array}{c}11 \mathrm{VI} \\
-22 \mathrm{IX}\end{array}$ & $\begin{array}{l}10 \mathrm{VII} \\
-28 \mathrm{VIII}\end{array}$ & August & July & August & $\begin{array}{c}1.11 \\
(11-12 \text { VIII) }\end{array}$ & $\begin{array}{c}4.93 \\
(20-21 \text { VIII) }\end{array}$ & $\begin{array}{c}0.92 \\
(5-6 \mathrm{VIII})\end{array}$ \\
\hline Artemisia & $\begin{array}{l}21 \mathrm{~V} \\
-6 \mathrm{IX}\end{array}$ & $\begin{array}{c}5 \mathrm{VII} \\
-31 \mathrm{VIII}\end{array}$ & $\begin{array}{c}24 \mathrm{VII} \\
-26 \mathrm{VIII}\end{array}$ & August & August & August & $\begin{array}{c}5.19 \\
(6-9 \mathrm{VIII})\end{array}$ & $\begin{array}{c}16.93 \\
(8-9 \mathrm{VIII})\end{array}$ & $\begin{array}{c}3.39 \\
(13-14 \text { VIII })\end{array}$ \\
\hline
\end{tabular}

Table 2

Pollen deposition and selected meteorological variables in Spearman's rank correlation analysis

\begin{tabular}{cccccccccccc}
\hline Taxon & $\begin{array}{c}\text { Average } \\
\text { temperature } \\
{\left[{ }^{\circ} \mathrm{C}\right]}\end{array}$ & $\begin{array}{c}\text { Maximum } \\
\text { temperature } \\
{\left[{ }^{\circ} \mathrm{C}\right]}\end{array}$ & $\begin{array}{c}\text { Minimum } \\
\text { temperature } \\
{\left[{ }^{\circ} \mathrm{C}\right]}\end{array}$ & $\begin{array}{c}\text { Dew point } \\
\text { temperature } \\
{\left[{ }^{\circ} \mathrm{C}\right]}\end{array}$ & $\begin{array}{c}\text { Humidity } \\
{[\%]}\end{array}$ & $\begin{array}{c}\text { Pressure } \\
{[\mathrm{hPa}]}\end{array}$ & $\begin{array}{c}\text { Wind speed } \\
{[\mathrm{m} / \mathrm{s}]}\end{array}$ & $\begin{array}{c}\text { Maximum } \\
\text { wind speed } \\
{[\mathrm{m} / \mathrm{s}]}\end{array}$ & $\begin{array}{c}\text { Precipitation } \\
{[\mathrm{mm}]}\end{array}$ \\
\hline Poaceae & $* 0.193762$ & 0.106885 & $* 0.316431$ & $* 0.274932$ & 0.111385 & -0.17432 & 0.023145 & $* 0.269669$ & $*-0.202616$ \\
Secale & $* 0.346184$ & 0.2089 & $* 0.386519$ & -0.207797 & -0.060353 & -0.139058 & 0.072664 & $* 0.318421$ & 0.163453 \\
Rumex & 0.056538 & $* 0.325204$ & 0.103402 & 0.099873 & $*-0.365763$ & $*-0.25471$ & -0.071524 & -0.060494 & 0.089981 \\
Plantago & 0.133451 & $* 0.363951$ & -0.048188 & $* 0.371155$ & 0.053996 & 0.069537 & 0.083258 & 0.047361 & $*-0.30539$ \\
Urtica & $* 0.414347$ & $* 0.349942$ & $* 0.338709$ & $* 0.309766$ & 0.180341 & -0.187436 & 0.085922 & -0.02152 & $*-0.357599$ \\
Chenopodiaceae & $* 0.518473$ & $* 0.44863$ & $* 0.369181$ & $* 0.282582$ & -0.238405 & 0.052272 & 0.086079 & 0.011756 & 0.007813 \\
Artemisia & 0.155392 & $* 0.376479$ & 0.094451 & 0.124209 & -0.034637 & 0.139188 & 0.163651 & $* 0.281461$ & -0.083617 \\
\hline
\end{tabular}

* Statistical significance $\mathrm{p}<0.05$

\section{DISCUSSION}

The pollen seasons of herbaceous plants are characterised by alternate periods of increased and decreased pollen count (M y s zkowska et al. 2007). Differences in the pollen count of these plants depend on the height above the ground at which sampling instruments are mounted. For instance, pollen traps installed at 15-25 metres above the ground level allow mean results for a large area to be obtained but give underestimated data for the pollen of small plants, since at this height their representation in the air is lower (L i p i e c et al. 2007). Also, in our study a much lower pollen count from herbaceous plants was recorded in Szczecin where the Durham pollen trap was at 21 metres above the ground than in Gudowo where the pollen trap was at 1.5 metre above the ground. Com- paring airborne pollen counts in a city and in a rural area, K a s przy k (2006) showed that the mean pollen count of Poaceae, Plantago, Rumex and Urtica was higher in the rural area. A similar result was obtained in our observations when comparing pollen deposition of the taxa studied in 2009 in Szczecin and in Gudowo.

In $2009 \mathrm{R}$ a pi j jko et al. (2009a) found high values of the daily grass pollen count. Leuschner et al. (2000) gave high annual sums of daily pollen counts of Poaceae in Basil (Switzerland) in 1969, 1985, 1989, and 1998, while Gi or a to et al. (2000) observed the same in Padua (Italy). L e ve ti n et al. (2000) indicated that May was the month of the highest monthly deposition of Poaceae pollen (249 pollen grains $\left./ \mathrm{cm}^{2}\right)$. In Szczecin and Gudowo the maximum monthly deposition of Poaceae pollen was in June. 
The pollen season of sorrel is long; in Szczecin and Gudowo it lasted for about 3 months, but the pollen deposition of this species was low. At both sampling sites, the maximum daily pollen deposition did not exceed a few grains per $\mathrm{cm}^{2}$. P i o trow sk a and W e r y s zk o- Ch mi e le w ska (2003) gave the annual Rumex pollen sum of 142 and 165 pollen grains in Lublin in the years 1997 and 1998. Similarly low values of sorrel pollen deposition were observed in Brussels (Belgium) by D e t a n d and Nolard (2000) in 1982-1997.

Low values of nettle pollen counts in the years 2002-2004 in Wrocław were noted by Malkie w i c z (2006). In their study of Urticaceae pollen counts in Trieste (Italy) during the period 1990-1999, L ong oet al. (2004) found that the peak of pollen production by this taxon usually occurred at the beginning of May and that the maximum daily pollen counts differed significantly in particular years. P i o trow ska and Weryszko-Chmielewska (2003) also reported different maximum daily pollen counts of Urtica in the years 1997-1998. In Gudowo the maximum nettle pollen count in 2009 was almost twice lower than in 2010. A low value of the Urtica pollen count was reported in Toulouse (France) by L e v e t i n et al. (2000) who gave the total annual pollen deposition of 46 pollen grains $/ \mathrm{cm}^{2}$ in 1997. In Gudowo, the annual nettle pollen count in 2009 was 61 grains $/ \mathrm{cm}^{2}$.

The maximum daily plantain pollen deposition was low both in Szczecin and Gudowo, and reached up to a few grains per $\mathrm{cm}^{2}$ in $24 \mathrm{~h}$. The highest plantain pollen count was reported by $\mathrm{R}$ a pi e j ko et al. (2010) in 2009 only on one day in Drawsko Pomorskie and in Szczecin. The total annual deposition of Plantago pollen in Toulouse (France) in 1997 was just 6 grains $/ \mathrm{cm}^{2}$ (L e vet in et al. 2000). Both total daily deposition and the percentage contribution of Plantago pollen to the pollen deposition of all the taxa studied were rather low. Rapiejk o et al. (2010) showed that airborne Plantago pollen counts had been low for many years. In 2009 low values of the Plantago pollen count were noted in Bialystok, Bydgoszcz, Krakow, Sosnowiec, Lublin and, Warszawa (R a p i e j k o et al. 2010). Also for the years 1982-1997, D e t a n d t and $\mathrm{N}$ ol ard (2000) reported a low mean annual sum of airborne Plantago pollen in Brussels (Belgium).

The highest Chenopodiaceae pollen deposition was recorded in the first half of July. According to L i p i e c et al. (2009), the highest pollen count of goosefoot occurs in August, while Le ve ti n et al. (2000) observed the maximum monthly pollen deposition 112 grains/cm, in this month. The maximum Chenopodiaceae pollen count has been reported for Bialystok, Bydgoszcz, Krakow, Lublin, Olsztyn, Sosnowiec, and Warsaw (L i p i e c et al. 2009). A comparison of the
Chenopodiaceae pollen season in Szczecin and $\mathrm{Gu}-$ dowo in 2009 shows that the total deposition in the city was more than twice lower than in the rural area. Similarly, low values of airborne Chenopodiaceae pollen counts in urban agglomerations were reported by Li i i e et al. (2009), and a low annual sum of this pollen was given by D e t a n d and Nolard (2000) in Brussels (Belgium) for 1982-1997.

The highest mugwort pollen deposition was noted in the middle of August; $R$ a p i e j k o et al. (2009 b) also found this date to be typical for the area of Poland. According to Weryszko-Chmielewska et al. (2007) and Li pi e c et al. (2008) the mugwort pollen season in Poland lasts from the second half of July to the middle of September. Artemisia pollen deposition was observed in Gudowo from the beginning of July to the end of August. The maximum daily pollen deposition values varied considerably from year to year. In Gudowo in 2009 the maximum pollen deposition was four times higher than in 2010. Large differences in the maximum pollen count of Artemisia between years have also been noted in Szczecin and other cities in Poland (Wrocław, Bydgoszcz, Bialystok, Olsztyn) (Chłopek et al. 2008; Rapiejko et al. 2009 b). The mugwort pollen season in Wrocław in 2002 lasted 86 days, while in the two subsequent years it lasted 81 and 79 days (Malkiewicz, 2006). In 2009 in Szczecin, mugwort pollen was present in the air for 109 days, while in Gudowo for 58 days.

The pollen of particular taxa can be found in the air for a few weeks after the end of flowering as the pollen grains are carried by air movements and the wind and when deposited, they can be lifted up again to be redeposited (R a piejko, 1997; Dybova-Jachowicz and Sadowska, 2003; Weryszko- Ch m i e l e w s k a et al. 2007). In both seasons studied, individual grains of Artemisia, Chenopodiaceae and Secale pollen were noted for a few weeks after their flowering had stopped. The pollen season is generally longer than the flowering period, since we take into account all airborne grains, also those originating from secondary deposition and long-distance transport. $\mathrm{R}$ a $\mathrm{n}$ t a et al. (2006) proved that phenological observations are not sufficient to determine the timing of the main pollen season because long-distance transport of pollen may greatly affect the timing of the local pollen season of studied taxa. The pollen of the studied taxa remains in the air in notable concentrations at the end of the pollination period and even after its end. Moreover, pollen shed timing depends on the type of habitat in which these individuals occur ( $\mathrm{K}$ a s p r z y k, 2010).

The influence of weather elements on the dynamics of bioaerosol particles has been studied by testing the correlations between the daily values of meteorological parameters and the sporomorph count in the air 
(Palacios et al. 2007). The analysis of our results has revealed a negative influence of humidity and a positive effect of temperature on the airborne pollen count. The effect of these weather conditions is related to the release and transportation of pollen grains (Piotrowska and Weryszko-Chmielewska, 2003; Palacios et al. 2007). The pollen count in general decreases with decreasing temperature and in the presence of precipitation (P e t e r n e l et al. 2004). Our results from Szczecin in 2009 have confirmed these correlations. Jo n nes and $\mathrm{Harr}$ is on (2004) have shown that the beginning of pollen shed of certain grass species is related to specific values of temperature, the length of daylight, and the presence of precipitation.

The long duration of the Poaceae pollen season is related to the large number of its species. Grass pollen deposition also depends on weather factors. Particular species produce pollen at specific temperatures and air humidity (Chło pe k et al. 2007). The effect of weather conditions on pollen release of certain taxa has been studied by E m b e r lin and N or r i s - H ill (1991) - Urticaceae, S pieks ma et al. (1985) and Gal a n et al. (1995) - grasses, Munuera Giner et al. (1999) - mugwort.

On the basis of a comparative analysis of the atmosphere in urban and rural areas, Kasprzyk (2006) showed that it depends on vegetation cover, weather, climate, and geographical conditions. The results obtained for Szczecin and Gudowo gave similar conclusions. The composition of pollen grains and pollen fall of herbaceous plants was found to depend on the urban or rural character of the area, type of local vegetation, weather, and the location of the pollen trap. An earlier occurrence of airborne pollen in Szczecin is explained by the presence of urban heat islands. The city's microclimate is characterised by a low level of relative air humidity, specific winds, increased content of aerosols, and higher frequency of fogs. Higher temperatures in the city can result in the extension of the growing season (K a s p r z y k, 2006). The earlier appearance of pollen in the air in the city is related to the formation of urban heat islands. The city affects plant phenology by reducing daily temperature fluctuations and increased minimum temperature ( $\mathrm{Mi}$ m e $\mathrm{t}$ et al. 2009).

\section{CONCLUSIONS}

1. Among the taxa studied, the family Poaceae is characterised by the longest pollen release period, while the family Artemisia by the shortest one. Grasses have the highest percentage contribution of pollen grains to the total airborne pollen count, reaching over $60 \%$.
2. The pollen seasons of individual taxa differed at the two study sites and in the two years of the study. Their beginning and duration depended on the location of the sampling site in the city and in the country as well as on habitat and weather conditions.

3. The pollen seasons of the majority of herbaceous plants studied occur from May to July, except for Chenopodiaceae and Artemisia whose pollen seasons come in August.

4. The majority of the taxa studied began flowering earlier in the city, although the mean airborne pollen count was higher in the rural area. The differences in the flowering pattern of rye, goosefoot, and mugwort in the years 2009 and 2010 are probably related to different weather conditions during these two seasons and biogeographic conditions at the sites of observation.

5. Most often, pollen deposition was positively correlated with maximum, minimum and mean air temperatures, dew point, and maximum wind speed, while negatively with precipitation.

\section{REFERENCES}

Chłopek K., Malkiewicz M., Myszkowska D., Kasprzyk I., Puc M., Balwierz Z., Majkowska-Wojciechowska B., Piotrowska K., Weryszko-Chmielewska E., Lipiec A., Siergiejko Z., Rapiejko P. 2007. Pyłek traw w powietrzu wybranych miast Polski w 2007 roku. / The grass pollen in the air of selected Polish cities in 2007. Alergoprofil, 3 (4): 43-49. (in Polish)

Chłopek K., Piotrowska K., WeryszkoChmielewska E Dąbrowska-Zapart K., Puc M., Malkiewicz M., Lipiec A., Winnicka I., Kalinowska E., Rapiejko P., Zielnik-Jurkiewicz B. 2008. Analiza stężenia pyłku bylicy w wybranych miastach Polski w 2008 roku. / The analysis of mugwort pollen count in selected Polish cities in 2008. Alergoprofil, 4 (4): 35-39. (in Polish)

Detandt M., Nolard N. 2000. The fluctuations of the allergenic pollen content of the air in Brussels (1982 to 1997). Aerobiologia, 16: 55-61.

Durham O.C. 1946. The volumetric incidence of airborne allergens. IV. A proposed standard method of gravity sampling, counting, and volumetric interpolation of results. J. Allergy Clin. Immunol. 17: 79-86.

Dybova-Jachowicz S., Sadowska A. 2003. Palinologia. Wyd. Instytutu Botaniki PAN, Kraków. (in Polish)

Emberlin J., Norris-Hill J.1991. Annual, daily and diurnal variation of Urticaceae pollen in North-central London. Aerobiologia. 7: 49-56. http://dx.doi.org/10.1007 /BF02450017

Emberlin J., Savage M., Woodman R. 1993. Annual variations in Betula pollen season in London 19611990. Grana, 32: 359-364. 
Galán C., Emberlin J., Domínguez E., Bryant B., Villamandos F. 1995. A comparative analysis of daily variations in the Gramineae pollen counts at Córdoba, Spain and London, UK. Grana, 34: 189-198. http://dx.doi.org/10.1080/00173139509429042

Giorato M., Lorenzoni F., Bordin A., De Biasi G., Gemignani C., Schiappoli M., Marcer G. 2000. Airborne allergenic pollens in Padua: 1991-1996. Aerobiologia, 16: 453-454.

Jones A., Harrison R. 2004. The Effects of Meteorological Factors on Atmospheric Bioaerosol Concentrations. A Review. Sci Total Environ. 326: 151-180. http://dx. doi.org/10.1016/j.scitotenv.2003.11.021

Kasprzyk I. 2006. Comparative study of seasonal and intradiurnal variation of airborne herbaceous pollen in urban and rural areas. Aerobiologia. 22:185-195. http://dx.doi. org/10.1007/s10453-006-9031-1

Kasprzyk I. 2010. Początek sezonów pyłkowych olszy i leszczyny a początek pylenia w różnych warunkach siedliskowych Rzeszowa. / Start of alder and hazel pollen seasons and start of pollination in different habitats in Rzeszów. Alergoprofil, 6(2): 32-37.

Koto E., Kishigawa R., Nishima S., Ishikawa T. 1998. Study of Airbone Pollen Counts using Durham's Sampler and IS-Rotary Pollen Trap in Fukuoka City for 12 Years. Jap. J. Palynol. 44 (2): 107-118.

Leuschner R., Christen H., Jordan P., Vonthe in R. 2000. 30 years of studies of grass pollen in Basel (Switzerland). Aerobiologia, 16: 381-391.

Levetin E., Rogers C., Hall S. 2000. Comparison of pollen sampling with a Burkard Spore Trap and a Tauber Trap in a warm temperate climate. Grana, 39: 294-302. http://dx.doi.org/10.1080/00173130052504333

Lipiec A., Malkiewicz M., Maj J., Puc M., Myszkowska D., Weryszko-Chmielewska E., Piotrowska K., Chłopek K., Modrzyński M., Stankiewicz W., Stasiak-Barmuda A. 2006. Stężenie pyłku traw w $2006 \mathrm{r}$. / The grass pollen count in 2006. Alergoprofil, 2 (3): 52-61. (in Polish)

Lipiec A., Chłopek K., Siergiejko Z., Weryszko-Chmielewska E., Malkiewicz M., Piotrowska K., Myszkowska D., Puc M., Maj J., Puc M., Rapiejko P. 2007. Analiza stężenia pyłku bylicy w wybranych miastach Polski w 2006 r. / The analysis of mugwort pollen count in selected Polish cities in 2006. Alergoprofil, 3 (1): 44-50. (in Polish)

Lipiec A., Puc M., Weryszko-Chmielewska E., Piotrowska K., Malkiewicz M., Maj J., Myszkowska D., MajkowskaWojciechowska B., Balwierz Z., Siergiejko Z., Rapiejko A., Ratajczak J., Wojdas A. 2008. Analiza stężenia pyłku bylicy w wybranych miastach Polski w 2007 roku. / The analysis of mugwort pollen count in selected Polish cities in 2007. Alergoprofil, 4 (1): 55-60. (in Polish)
Lipiec A., Rapiejko P., Weryszko-Chmielewska E., Piotrowska K., Myszkowska D., Buczyłko K., Wagner A., Puc M., Malkiewicz M., Chłopek K., Stasiak-Barmuda A., Zielnik-Jurkiewicz B., Staroń K., Stankiewicz W. 2009. Analiza stężenia pyłku komosy w wybranych miastach Polski w 2009 roku. / The analysis of goosefoot pollen count in selected Polish cities in 2009. Alergoprofil, 5 (3): 47-50. (in Polish)

Longo L., Sauli P., Ganis P. 2004. Aerobiology of Urticaceae pollen in Trieste (NE Italy). Aerobiologia, 20: 53-61.

Łukasiewicz A. 1984. Potrzeba ujednolicenia metody fenologicznej w polskich ogrodach botanicznych i arboretach. / The need to standardise the phenological method in Polish botanical gardens and arboreta. Wiadomości Botaniczne, 28 (2):153-158. (in Polish)

Malkiewicz M. 2006. Pyłek bylicy (Artemisia L.), pokrzywy (Urtica L.) i babki (Plantago L.) w powietrzu Wrocławia w latach 2002-2004. / The pollen of mugwort (Artemisia L.), nettle (Urtica L.), and plantain (Plantago L.) in the air of Wrocław in 2002-2004. Acta Agrobot. 59 (1): 347-354. (in Polish)

Munuera Giner M, Carrión García J.S, García Sellés J. 1999. Aerobiology of Artemisia airborne pollen in Murcia (SE Spain) and its relationship with weather variables: annual and intradiurnal variations for three different species. Wind vectors as a tool in determining pollen origin. Int J. Biometeorol. 43 (2): 51-63.

Mimet A., Pellissier V., Quénol H., Aguejdad R., Dubreuil V., Rozé F. 2009. Urbanisation induces early flowering: evidence from Platanus acerifolia and Prunus cerasus. Internat. J. Biometeorol. 53. 287-298. http://dx.doi.org/10.1007/s00484-009-0214-7

Myszkowska D., Jenner B., Puc M., Stach A., Nowak M., Malkiewicz M., Chłopek K., Uruska A., Rapiejko P., MajkowskaWojciechowska B., Weryszko-Chmielewska E., Piotrowska K., Kasprzyk I. 2010. Spatial variations in the dynamics of the Alnus and Corylus pollen seasons in Poland. Aerobiologia, 26: 209-221. http://dx.doi.org/10.1007/s10453-010-9157-z

Myszkowska D., Puc M., Nowak M. Stach A., Malkiewicz M., Chłopek K., Majkowska-Wojciechowska B., Rapiejko P., Siergiejko Z., Weryszko-Chmielewska E., Piotrowska K. 2007. Analiza sezonów pyłkowych babki w wybranych miastach Polski w roku 2007. / The analysis of the plantain pollen seasons in the selected Polish cities in 2007. Alergoprofil, 3 (4): 50-56. (in Polish)

O'Rourke M. 1990. Comparative pollen calendars from Tuscon, Arizona: Durham vs. Burkard samplers. Aerobiologia, 6: 136-140.

Palacios I., Molina R., Rodriguez A. 2007. The importance of interactions between meteorogical conditions when interpreting their effect on the dispersal of pollen from homogeneously distributed sources. Aerobiologia, 23:17-26. 
Peternel R., Srnec L., Culig J., Zaninovic K., Mitic B., Vukusic I. 2004. Atmospheric pollen season in Zagreb (Croatia) and its relationship with temperature and precipitation. Int. J. Biometeorol. 48: 186-191. http://dx.doi.org/10.1007/s00484-004-0202-x

Pidek I. A. 2006. Zmienność rocznego opadu pyłku wybranych taksonów na Roztoczu Środkowym (Polska SE) w latach 2001-2005. / Variation in annual pollen deposition of selected taxa in Central Roztocze (SE Poland) in 2001-2005. [In:] (Ed). Weryszko-Chmielewska E. Pyłek roślin w aeroplanktonie różnych regionów Polski. Wyd. Katedry i Zakładu Farmakognozji Wydz. Farmaceutycznego Akademii Medycznej w Lublinie, Lublin, 117-132. (in Polish)

Pidek I.A., Piotrowska K., Kaszewski B.M., Kalnina L., Weryszko-Chmielewska E. 2009; Airborne birch pollen in Poland and Latvia in the light of data obtained from aerobiological monitoring and Tauber traps in relation to mean air temperature. Acta Agrobot. 62 (2): 77-90.

Piotrowska K., Weryszko-Chmielewska E. 2003. Pollen count of selected taxa in the atmosphere of Lublin using two monitoring methods. Ann Agric Environ Med. 10: 79-85.

Puc M. 2011. Threat of allergenic airborne Grass pollen in Szczecin, NW Poland: the dynamics of pollen season, effect of meteorological variables and air pollution. Aerobiologia, 27:191-202. http://dx.doi.org/10.1007/ s10453-010-9188-5

Ranta H., Kubin E., Siljamo P., Sofiev M., Linkosalo T., Oksanen A.2006. Long distance pollen transport cause problem for determining the timing of birch pollen season in Fennoscandia by using phenological observations. Grana, 45: 397-304. http://dx.doi. org/10.1080/00173130600984740

R a piejko P. 1997. Alergeny pyłku roślin. / Plant pollen allergens. Alergia Astma Immunologia, 2(1): 9-18. (in Polish)

Rapiejko P., Weryszko-Chmielewska E. 1999. Pyłek bylicy. / Mugwort pollen. Alergia Astma Immunologia, 4 (3): 139-142. (in Polish)

Rapiejko P., Lipiec A. 2005. Pyłek traw - aerobiologia, charakterystyka alergenów i aspekt kliniczny. / The grass pollen - aerobiology, allergens' characteristics and clinical aspect. Alergoprofil, 2 (2): 40-49. (in Polish)

Rapiejko P., Lipiec A. 2006. Wybrane aspekty alergii krzyżowej. / The selected aspects of cross-allergenicity. Alergoprofil, 2 (2): 11-15. (in Polish)

Rapiejko P., Buczyłko K., Wagner A., Puc M., Malkiewicz M., Chłopek K., ZielnikJurkiewicz B., Myszkowska D., StasiakBarmuda A., Wawrzyniak M., Stankiewicz W. 2009. Pyłek traw w powietrzu wybranych miast Polski w 2009 roku. / The grass pollen in the air of selected Polish cities in 2007. Alergoprofil, 5 (3): 36-40. (in Polish)
Rapiejko P., Zielnik-Jurkiewicz B., Myszkowska D., BuczyłkoK., Wagner A., Puc M., Malkiewicz M., Chłopek K., Stasiak-Barmuda A., Szczygielski K., Dżaman K., Wawrzyniak Z., Staroń K., WeryszkoChmielewska E., Piotrowska K., Stankiewicz W. 2009. Analiza stężenia pyłku bylicy w wybranych miastach Polski w 2009 roku. / The analysis of mugwort pollen count in selected Polish cities in 2009. Alergoprofil, 5 (3): 43-46. (in Polish)

Rapiejko P., Lipiec A., Buczyłko K., Wagner A., Staroń K., Puc M., Malkiewicz M., Chłopek K., Weryszko-Chmielewska E., Piotrowska K., Wawrzyniak M., ZielnikJurkiewicz B., Usowski J., Szczygielski K., Chciałowski A. 2010. Analiza stężenia pyłku babki w wybranych miastach Polski w 2009 roku. / The analysis of plantain pollen count in selected Polish cities in 2009. Alergoprofil, 5 (1): 40-44. (in Polish)

Spieksma F.Th.M, van den Assem A., Collette B. 1985. AirbornePollenConcentrationinLeiden, The Netherlands, 1977-1981. Grana, 24 (2): 99-108. http://dx. doi.org/10.1080/00173138509429920

StatSoft, Inc., 2008. STATISTICA (data analysis software system), ver. 9.0. www.statsoft.com.

Szweykows cy A., J. 1995. Botanika. Systematyka. Wyd. Naukowe PWN, Warszawa. (in Polish)

Szweykowscy A., J. 1993. Słownik botaniczny. Wyd. Wiedza Powszechna, Warszawa. (in Polish)

Weryszko-Chmielewska E., Piotrowska K. 2004. Airborne pollen calendar of Lublin, Poland. Ann Agric Environ Med. 11: 91-97.

Weryszko-Chmielewska E., Kasprzyk I., Myszkowska D., Piotrowska K., Puc M., Smith M., Stach A., Stępalska D., Urusk a A. 2007. Aerobiologia. Wyd. Akademii Rolniczej w Lublinie. Lublin. (in Polish)

Zawisza E., Samoliński B., Tarchalska B., Rapiejko P. 1993. Allergenic pollen and pollinosis in Warsaw. Aerobiologia, 9: 47-51. http://dx.doi.org/10. 1007/BF02311370

\section{Fenologia kwitnienia i pylenia wybranych roślin zielnych \\ w Szczecinie i Gudowie (Pomorze Zachodnie) a ryzyko alergii pyłkowej}

\section{Streszczenie}

Praca przedstawia przebieg sezonu pyłkowego wybranych roślin zielnych (Secale spp., Rumex spp., Plantago spp., Urtica spp., Artemisia spp., Chenopodiaceae i Poaceae) oraz przebieg kwitnienia Chenopodium album L., Artemisia vulgaris L. i Secale spp. Badania opadu pyłkowego prowadzono metodą grawime- 
tryczną, przy użyciu aparatu Durhama, w dwóch punktach pomiarowych, w środowisku miejskim (Szczecin) oraz wiejskim (Gudowo). W 2010 r. okres kwitnienia badanych taksonów był krótszy niż w 2009 a jego rozpoczęcie obserwowano później, maksymalne wartości dobowego opadu pyłkowego były niższe. Ziarna pyłku większości badanych taksonów wcześniej pojawiały się $\mathrm{w}$ atmosferze miasta, natomiast na wsi odnotowano znacznie wyższe wartości dobowego opadu. Wcześniejsze zakwitanie roślin w środowisku miejskim zostało prawdopodobnie spowodowane wpływem podwyższonej temperatury w miastach $\mathrm{w}$ porównaniu z obszarami podmiejskimi czy znajdującymi się poza miastami. Analiza opadu pyłkowego w Szczecinie w 2009 roku w powiązaniu z elementami pogody wykazała, że najczęściej skorelowane z obecnością pyłku w atmosferze były: temperatura maksymalna, minimalna oraz średnia, temperatura punktu rosy i maksymalna prędkość wiatru - dodatnio, natomiast opady atmosferyczne - ujemnie. 